\title{
Qualitative Analysis of Legume Pericarp (Pod Wall) and Seeds of Acacia Farnesiana L.
}

\author{
Sanjay Biradar, Bhagyashri Rachetti \\ Tissue Culture Research Center \\ Dept. of Botany, Shri Chhatrapati Shivaji College Omerga - 413606, Dist. Osmanabad, (MS). INDIA
}

\begin{abstract}
Present study deals with the qualitative analysis of ethanolic extract of Legume pericarp (pod wall) and seeds of Acacia farnesiana (L). In which we analyze 22 Phytochemical, which are use full for controlling the diseases in Human beings. In India, Acacia farnesiana L. is known as Mulla tumma, Kampu tumma in local area and it is commonly known as Aroma and sweet acacia also. The aim of the present study is to investigate the presence or absence of phytochemicals such as Flavonoids, Alkaloids, Steroids, Proteins, Carbohydrates, Tannin, Amides, Terpenoides, Amines, Phenol, Test for Unsaturation, Carboxylic acid, Test for $\mathrm{NH}_{2}$, Nitrogen, Sulphur, Halogen, Starch, Saponin, Ascorbic acid, Glycosides, Reducing Sugar and Triterpenoids contents of the selected medicinal plants. The ethanolic extract of legume pericarp indicates the presence of major bioactive compound compare to seeds.
\end{abstract}

Keywords: Acacia fernesiana L., qualitative analysis, bioactive compound.

\section{Introduction}

Acacia farnesiana L. grown throughout India, and often planted in gardens. If we see its yield, in India and other Eastern countries produce much for local use and Trees begin to flower from the third year, mainly from November to March. The bark of this plant is used as astringent and demulcent. The leaves and roots are used for medicinal purposes. Woody branches used in India as tooth brushes. The gummy roots also chewed for sore throat. The roots of this plant are also used for the antispasmodic, aphrodisiac, astringent, demulcent, diarrhea, febrifuge, rheumatism, and stimulant[1].

The plant is also used as diuretic, treat antiulcer, anti-pyritic etc. Absence of evidence on anti-diabetic activity of Acacia farnesiana let us embark on this study with an aim to scientifically prove the traditional claim of this plant[2] . Diabetes Mellitus (DM) is a major degenerative disease [3][4] affecting at least $10 \%$ of the population, worldwide. Complications of DM include hypertension, atherosclerosis, microcirculatory disorders, retinopathy, nephropathy, neuropathy and angiopathy[5].

Sweet Acacia is occasionally used as folk remedy by population in areas where it grows abundantly. However, it can hardly be considered as a medicinal plant of widespread usage. It's essential oil, either as a concrete or aas an absolute, has never been used in traditional medicine. It was recently introduced in aromatherapy[6].

The pods are very characteristic, resembling a beaded necklace which are flat, straight or slightly curved, and fleshy when young with reddish hairs, becoming dark blackish when mature. The pods are sweetly scented when crushed and contain a sticky fluid [7].

The pods of A. fernesiana were shown to contain gallic acid and a few derivative (ellagic acid, m-digallic acid, Methyl gallet), various flavonoids ((kaemferol, aromadendrin, diosmetin and narin genin), their glycoside and and galloylglucosides. Tannins were found in significant quantities in the leaves and pods but above all, in the back of tree[8][9][10][11][12].

\subsection{Collection of Material:-}

\section{Materials And Methods:-}

The fresh parts of Acacia farnesiana (L) were collected from Omerga Tq.Omerga, Dist. Osmanabad, Maharashtra. The plant material were properly washed with tap water and then rinsed with distilled water, dried in oven at $60^{\circ} \mathrm{C}$ until plant parts became well dried for grinding. After drying, the plant materials were ground well into fine powder.

\subsection{Extraction}

2.2.1 Preparation of ethanolic extracts from different plant parts (Legume pericarp and seeds):-

For preparation of ethanolic extract, a modified method of Abdulrahman et.al (2004)[13] was used. The fresh parts of the plant were dried in oven and ground to fine powder with mechanical grinder. Ten gram of each plant parts was then macerated in $100 \mathrm{ml}$ of absolute ethanol for $48 \mathrm{hr}$. \& properly covered with foil \& 
labeled. After $48 \mathrm{hrs}$ of extraction, each extract was filtered through Whatman's filter paper no.1 separately. The filtrate was evaporated to dryness at room temperature \& store at $5^{0} \mathrm{C}$ in refrigerator.

\subsection{Qualitative analysis}

Qualitative phytochemical analyses were done using the procedures of Kokate, 1994[14] for Alkaloids, carbohydrates, tannins, phenols, flavonoids, and saponins. For Carboxylic acid, test for $\mathrm{NH}_{2}$, Nitrogen, Sulphur, Halogen, Amides, test for Unsaturation, test for Aromaticity[15]. Test for Starch, Steroids, Proteins, Glycosides, Reducing sugar \& Ascorbic Acid[16], test for Amino acid [17], Liebermann - Burchard's test for Triterpenoides, Terpenoides were qualitatively analyzed.

\section{Results \& Discussion}

The phytochemical analysis of Acacia farnesiana (L) tested were summarized in Table.1. Which reveled that presence of medicinally active compound in plant. From Table.1 it is concluded that, Legume pericarp (pod wall) contain maximum phytoconstituents than seeds of Acacia. Proteins, Carbohydrate, Tannin, Phenol, Alkaloid, Terpenoid, Steroid, Flavonoids are present in pod wall with maximum quantity. Ascorbic acid and Saponin are absent in pod wall.

Protein, Tannin, Alkaloid, Terpenoid, Steroid are present in seeds of Acacia frenesiana with small quantity. Carbohydrate, Saponin, Ascorbic acid are absent in seeds.

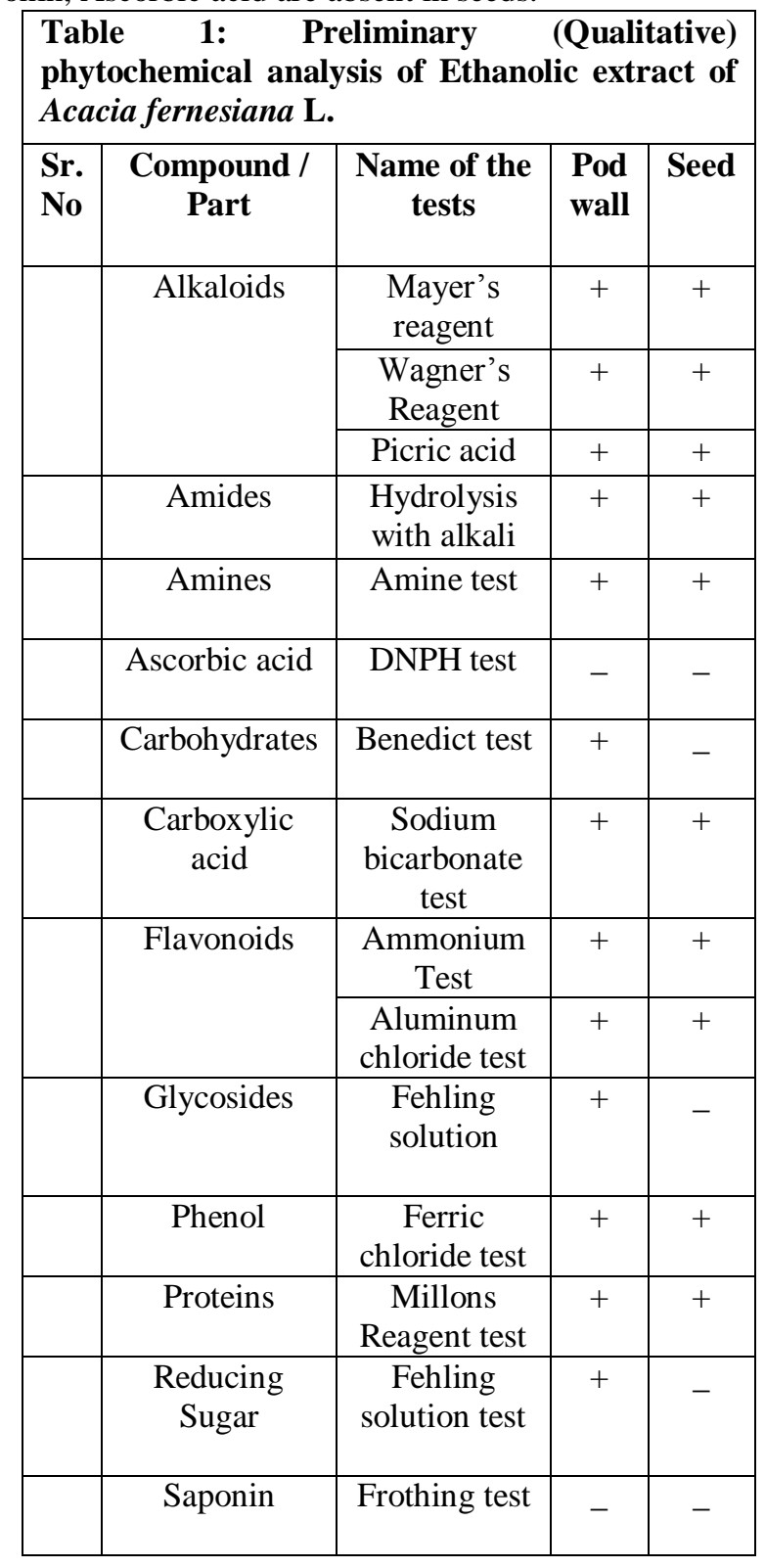




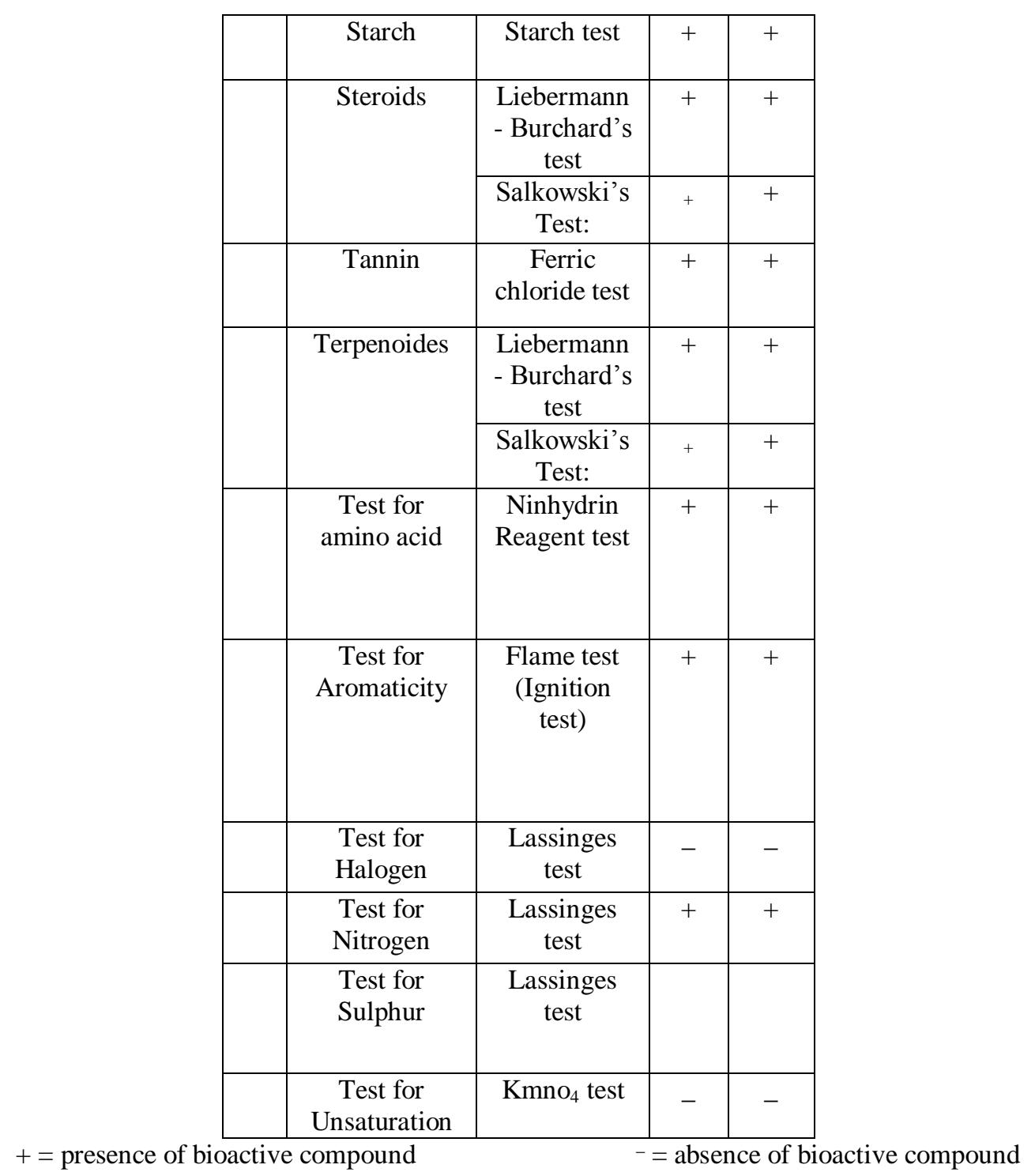

\section{Acknowledgement}

Author Dr. Sanjay R. Biradar is grateful thanks to Principal of Shri Chhatrapati Shivaji College, Omerga, Dist. Osmanabad, (M.S.), India for providing all necessary facilities and encouragement for the present research work.

\section{References:}

[1]. Duke, J.A. 1981a. Handbook of legumes of world economic importance. Plenum Press. New York.

[2]. R. Bino Kingsley,S. Aravinth Vijay Jesuraj , P. Brindha,A. Subramoniam, Atif M,(2013) International Journal of PharmTech Research CODEN (USA): IJPRIF ISSN : 0974-4304,

[3]. King H, Auberti RE, Herman WH. Global burden of diabetes, 1995-2025: prevalence, numerical estimates, and projections. Diabetes Care 1998;21:1414-1431.

[4]. Ogbonnia SO, Odimegwa JI, Enwaru VN. Evaluation of hypoglycemic and hypolipidemic effects of ethanolic extracts of Treculia Africana Decne and Bryophyllum pinnatum Lam. And their mixture on streptozotozin (STZ)- induced diabetic rats. African Journal of Biotechnology.2008;7(15):2535-2539.

[5]. Edem DO. Hypoglycemic effects of ethanol extracts of alligator pear seed in rats. European Journal of Scientific Research 2009;33:669-678

[6]. Watt M. aroma medical. Oils hyped by aromatherapy suppliers to increase their soles. Accessed on 10/11/07 from http://www.aromamedical.com/articles/hypedoils.htm

[7]. Swarbrick, J.T. (1997). Weeds of the Pacific Islands. Technical paper no. 209. South Pacific Commission, Noumea, New Caledonia. Pp. 124.Vol.5, No.1, pp 112-118, Jan-Mar 2013

[8]. EI Sissi HI. EI Ansari MA, EI Negoumy SI, Phenolics of Acacia fernesiana, phytochemistry 12:2303,1973.

[9]. EI Sissi HI, Saleh NAM, EI Negoumy SI, Wagner H, Iyengar MA, Seligmann O.Prunin-o-6"-gallate fromAcacia fernesiana,phytochemistry 13:2843-2844,1974.

[10]. Barakal HH, Souleman AM,Hussein SAM, Ibrahiem OA, Nawwar NAM, Flavonoid galloyl glucosides from pods of Acacia fernesiana, phytochemistry, 51:139-142,1999. 
[11]. Sahu NP, Achari B, Banerjee S.Dihydroxy methoxyflavone from seeds of Acacia fernesiana.phytochemistry,38:1425-1426, 1998.

[12]. Rama Devi S and Prasad MNV.Tannins and related polyphenols from ten common Acacia species of India,Biores,Technol.,36:189192,1991 .

[13]. Abdulrahman F, Inyang SI, Abbah J, Binda L, Amos S, Gamaniel K (2004). Effect of aqueous leaf extracts of Irvingia gabonesis on gastrointestinal tracts of rodents. India J. Exp. Biol. 42:787-791.

[14]. Kokate, C. K. 1994. Practical Pharmacognosy, 3rd Ed, Vallabh Prakashan, NewDelhi

[15]. Hans Thacher Clarke (2007). A Handbook of Organic Analysis, IV Edn., CBS Publishers, New Delhi.

[16]. Arun Sethi ( 2003) Lab Experiments in Organic Chemistry, New Age International (P) Limited, Publisher, ISBN 81 - 224-1491-5.

[17]. Pratibha Devi- 2003 Principles and Methods of Plant Molecular Biology, Biochemistry \& Genetics. Agrobios (INDIA). 